Trivent Publishing

(C) The Authors, 2015

Available online at http://trivent-publishing.eu/

Philosophy, Communication, Media sciences Series

Volume Saint Gerard of Cenad: Tradition and Innovation

\title{
Christological Accents in "The Lives of Saints" and Their Impact in the Social and Religious Formation of Believers
}

\author{
Iacob Coman \\ Pentecostal Theological Institute, Bucharest, iacob_coman@yahoo.com
}

\begin{abstract}
In the history of literature, hagiography is taken as a literary rudimentary-religious dowry through which the foundations of later literature are set. Usually, these writings are given a mythological-historical value which is why they are not considered clear segments of literature, while from the perspective of literary historians, they are not acknowledged as sacred writings either.

The present research provides a meeting point between the Protestant dogmatic theology and the lives of saints. That is, a general observation on how the lives of saints (and not only) contain the traits of the holy man and the characteristics of holiness of our Lord Jesus Christ. Given the importance that Jesus Christ gives to holiness, this article will show how the Holy Spirit has maintained in the saints the existential character of our Lord Jesus Christ and the basic paradigms of the life He desired.

In the conclusions of this study we will report the perspective of Jesus Christ on holiness and the life of repentance, and the way in which the Tradition preserved them. Details on how the life of St. Gerard of Cenad preserved and gave new insights to holiness and to the social life preached by Jesus Christ will also be presented.
\end{abstract}

Keywords: Jesus' holiness; holiness of people; life of repentance; holiness tradition; holiness as prospects for the future.

This is an Open Access article distributed in accordance with the Creative Commons Attribution Non Commercial (CC-BY-NC-ND 4.0) license, which permits others to copy or share the article, provided original work is properly cited and that this is not done for commercial purposes. Users may not remix, transform, or build upon the material and may not distribute the modified material (http://creativecommons.org/licenses/by-nc/4.0/)

DOI: 10.22618/TP.PCMS.20151.176015 


\section{Introduction}

Reducing the Holy Scriptures to a radical synthesis, from the perspective of the development of the salvation of God's people, we find that the entire Bible is a history of meditation on life, customs, beliefs, and ideals of God's people. Starting with the second century AD, the salvation of God's people continues. The writings of the Apostles are canonized, marking - in the living memory of Christianity and in its written memory the information regarding some Christians who remained as landmarks in the history of ministry.

In this research, which is different from historiography, hagiography and other writings on saints, but not excluding them, we will evoke the portrait of St. Gerard of Cenad in a surprising manner of dogmatic theology, in terms of theological discourse, his impact and religious dimension. Our research unfolds in Protestant manner, uncritical and lacking polemical arguments. The scientific discourse responds to the rigours of scientific research, but also the rigours of the biblical text, taking account of the religious literary qualities ranging from hagiography, from the dogma on saints and sanctification to the complexity of the historical discourse regarding impact of the lives of some Christians.

Under these conditions, we call into question in a textual biblical manner, from a theological perspective, some biblical ideas regarding the birth of saints, especially regarding the birth of Saint Jesus Christ. We do this in order to understand if both the ideas of sacred and holy lives derive, through reflection, from God. Setting this paradigm we continue with the thesis regarding belonging. Saints belong to God and His community. In other words, holiness does not isolate us, but gives saints back as examples to the society and the community of the redeemed, as a sample of life to be immortalized. We are already talking about a remembrance of the saints, that is, an inheritance which is the subject of God's pride and the object of His happiness.

In the last part of our research we will appropriate the life, work, the quality, and historical impact of St. Gerard of Cenad, in terms of theological ideas regarding the birth of the saints, the belonging of the saints and the memory of the saints. The fourth part, Saints image in St. Gerard of Cenad, proposes and develops the collective holiness of Gerard of Cenad's ancestors and how it is updated in him, so that, later on, he remains alive for future generations.

The entire dogmatic scientific discourse aims to detect the Christological accents in the life of true believers and their later impact on the social formation of Christians, as well as their religious formation. Addressing this topic and the way the subject is dealt with can be an inter-confessional challenge and, at the same time, a sample regarding the discussion on a dogma that radically separates the theology of the traditional churches from the evangelical ones.

\section{The Birth of Saints}

The idea of saints necessarily involves taking into account the Incarnation of our Lord Jesus Christ, both in terms of prophecy, that is the writings of the Old Testament, and in terms of its fulfilment, meaning, the New Testament writings.

The Old Testament considers the Incarnation of our Lord Jesus Christ from many perspectives, the most significant being: Immanuel - "God is with us"1 ("Therefore the Lord himself shall give you a sign; Behold, a virgin shall conceive, and bear a son, and shall call his name Immanuel." (Isaiah 7:14)), "Prince of Peace" ("For unto us a child is born, unto us a son is given: and the government shall be upon his shoulder: and his name shall be called Wonderful, Counsellor, The mighty God, The everlasting Father, The Prince of Peace." (Isaiah 9:6)) and "the Holy One" ("Because you will not leave my soul in hell, neither will you suffer your Holy One to see corruption" (Psalms 16:10). These Biblical notations on Jesus Christ provide us, from several Old Testament perspectives, the complexity of this saintly status. Immanuel, God with us, the name given to Jesus "when He was born as a man" ${ }^{2}$ indicates the presence of God among men, and with them, in terms of His holiness, justice and providence. Prince of Peace, that is, the God of conciliation, suggests holiness from the perspective of relationships between Him and man. Between God and men, the fellowship can only take place under the auspices of bringing to a common denominator of the existential condition,

\footnotetext{
${ }^{1}$ Anania Valeriu Bartolomeu, Cartea profetului Isaia [The Book of Prophet Isaiah] (Bucharest: Anastasia Publishing, 1999), 48.

${ }^{2}$ Tertulian Langa, Dicţionar teologic creştin din perspectiva ecumenismului catolic [Christian Theological Dictionary from the Perspective of Catholic Ecumenism] (Cluj-Napoca: Dacia Publishing, 1997), 86.
} 


\section{\begin{tabular}{l|l} 
I. Coman & 164
\end{tabular} \\ Christological Accents in "The Lives of Saints" and Their Impact in the Social and Religious Formation of Believers}

that of holiness. The message of the angel to the shepherds on the hills of Bethlehem was clear: "Glory to God in the highest, and on earth peace, good will toward men." (Luke 2:14) In other words, the reign of peace and God's peace are relevant only in those who please Him - that is, those who acquire the holiness that comes from God. The expression "Your Beloved," from Psalm 16, is not less significant in the sense of the idea of holiness. On the contrary, quoting Psalm 16, the Apostle Peter reveals the semantic fullness of the expression "Your Beloved" stating in flagrante "your Holy One." "Therefore did my heart rejoice, and my tongue was glad; moreover also my flesh shall rest in hope: Because you will not leave my soul in hell, neither will you suffer your Holy One to see corruption." (Acts 2:27) Evoking the appellation "Your Beloved" from Psalm 16 and replacing it with "your Holy One" exceeds the status of spiritual interpretation and necessarily requires a qualitative content. Being God's beloved one involves being God's holy man.

In the New Testament, the situation does not change at all. The dialogue between the Archangel Gabriel and Mary clearly appreciates this quality of Jesus, Man-God, when these words are said: "And the angel answered and said unto her, The Holy Ghost shall come upon you, and the power of the Highest shall overshadow you: therefore also that holy thing which shall be born of you shall be called the Son of God." (Luke 1:35). The human nature of Jesus Christ is clearly associated with holiness. Jesus Man-God is the Saint. This is "the sublime statement of the Incarnation." ${ }^{3}$ The way in which Jesus identifies Himself through His humanity with men, becomes the sample for the way in which men will identify themselves through holiness with Jesus and, thereby, with God.

When we talk about saints referring to people, we refer to a life that tends to overlap as much as possible with the life and ministry of our Lord Jesus Christ. The Greek agios, implies someone or something "devoted to God; that appropriates or learns the state of holiness and reaches sanctification and that is holy." This cannot be foreign to those who have met Christ. In other words, each person who has known Christ and was born again must have holiness as the essence of his existence.

On this New and Old Testamentary pattern, mentioned above, certain conclusions concerning the birth of saints and their existence are required. The biblical commandment "Because it is written, Be you holy; for I am holy" (1 Peter 1:16) does not envisage a strange category of believers, but implies a state of normality and sought among those who are Christians. The saints are born! For this reason, those who are born again through Baptism specifically accede to a life of holiness and the status of saints. Moreover, if for Peter the appellative "Your Beloved" can be understood as "Your Holy One," by analogy all appellatives, "dearly beloved," from the New Testament, used by Paul, Peter, John, Judah, etc. can be understood in this sense: You, saints! In these circumstances the idea of holiness must be an existential and relational landmark to every believer, more evident to those who are canonized.

In conclusion, when we talk about the birth of saints, we are talking about a group of people who live through Christ. The most obvious Christic accent in Christian life must be holiness. This order of existence is not about standardizing ethics and human civilization based on humanistic cohabitation, but this holiness is related to the way in which we commit our lives in communion with God as liturgical act, i.e. the participation in the Holy Eucharist, and as a way of being, that is our deification. As a liturgical act, that is the communion with the Body and Blood of the Lord Jesus Christ, we talk about "a wedding of the soul with the groom Christ," sanctity. This reality represents and recognizes our quality of being holy. As a way of being, it considers the deification of the human being, "a development through grace of a potency implanted in man," ${ }^{6}$ a development through which the communality of our existence is a divine one. This complex phenomenon in its Eucharistic and deifying dimension, expresses the birth that took place in the lives of believers. Under these conditions, the expression "that holy thing which shall be born of you" (Luke 1:35) finds its fulfilment and reflection in the expression saints who will be born from Him.

\footnotetext{
3 Macdonald William, Comentariu la Noul Testament [Commentary on the New Testament] (Bielefeld: CLV Christliche Literatur-Verbreitunge.V., 1998), 194.

${ }^{4}$ Ioan Mircea, Dicţionar al Noului Testament [Dictionary of the New Testament] (Bucharest: Publishing House of the Mission and Bible Institute of the Romanian Orthodox Church, 1995), 473.

${ }^{5}$ Nichifor Crainic, Sfinţenia împlinirea umanului [Holiness, Human Fulfillment] (Iaşi: Publishing House of the Metropolitan of Moldavia and Bukovina, 1993), 117.

${ }^{6}$ Dumitru Stăniloae, Trăirea lui Dumnezeu în ortodoxie [Experiencing God in Orthodoxy] (Cluj-Napoca: Dacia Publishing, 1993), 182.
} 


\section{God's Saints}

The idea of being God's saints, necessarily involves their recognition and accreditation. We are dealing with a declaration of memberships where the communion between man and God as well as the process of sanctification which man has joined to, is clearly highlighted. Talking about the saints of God, involves, once more, talking about Jesus Christ. In Him we have the model and reality of such accreditation and belonging. When Jesus Christ enters the synagogue in Capernaum He encounters a demonized man who inquires, through the demon that possesses him, Christ's status: "Saying, Let us alone; what have we to do with you, you Jesus of Nazareth? Have you come to destroy us? I know who you are, the Holy One of God!" (Mark 1:24)

This accreditation of Jesus Christ is a parable in which the identity of each of His followers must be retrieved. The cornerstone of saintly behaviour was and remains martyrdom. St. Ignatius of Antioch wore the spell of this accreditation since his lifetime: "Martyrdom - notes Jian Laporte on Ignatius - it is the testing through which he must clearly prove he is a disciple by his deeds; but when unsuccessful, there are only words and he is a liar. The general rule of imitating God and Christ means to him (St. Ignatius of Antioch) the need to follow Christ in His Passion and to bear His cross." 7 That is to be a martyr.

Talking about the saints of God, implies talking about people who "take part to the holiness of God, the supernatural life of God." 8 This, which is an accreditation and existential phenomenon, should be seen as a necessity for every believer, in general, and as a title for every canonized saint, especially. The Apostle Paul, speaking to believers in Philippi uses the following words: "Let us therefore, as many as be perfect, be thus minded: and if in anything you be otherwise minded, God shall reveal even this unto you" (Philippians 3:15). The expression "many as be perfect" envisages the accreditation of a Christian community, of a people who belonged to God through Jesus Christ. In the past, "saints were called all the Christians that, cleansed from sin by the grace of Baptism remained in it and increased it; we speak thus about all the saints and even about brothers saints." ${ }^{9}$ These people, this mass of believers is the Church. Approaching the Church of Christ necessarily implies going towards holiness, because it is holy and in it holiness is celebrated and the affiliation is declared. "The Church is defined simultaneously - notes Boris Bobrinskoy that is through the work of Christ and the presence of the Holy Spirit, both of Whom are the two hands of the Father, this double intercession making us sons of the Father." ${ }^{10}$ But this simultaneity is considering the believer that becomes a member of this "body" and participates in the life and holiness of this existential Body.

Therefore, when we talk about God's saints and their impact on social and religious formation of the faithful, we speak about the participation of each of us. In and through us the life and holiness of the Church is extended into the world. The connection between Church and us through a saint is one of continuity, of transfer of holiness from God towards and into believers. It does not have to be one of separation or substitution. All the saints in the biblical history commit themselves in experiencing the Body of Christ, serving and being served by all other "members," thus placing the body in an inseparable communion with Him Who is the Head, that is Jesus Christ. The saints of God are thus the Church, the Church as a place of love and of expressed love. Christological accents in the lives of the saints of God are not theological, but communional. The meeting between the saints of God as Church and into the Church, is the feast of love. In this theandric reality "love is a huge plus of knowledge while producing a huge plus of life in the beloved and the lover, dissolving to maximum his being and mine."11 In other words, we take part in the formation of the heavenly identity.

Those who bear the emblem of canonized saints have to have this quality to spring the love for heavenly identity. At the same time they dissolve their history in our history by participating in "our" formation, that is the Body of Jesus Christ that captures the existence of every believer from the perspective of unity, communion and love with Him Who is the Head. In these circumstances the Christological records in the

\footnotetext{
${ }^{7}$ Jian Laporte, Părinţii greci ai Bisericii [Greek Fathers of the Church] (Târgu Lăpuş: Galaxia Gutenberg Publishing, 2009), 6.

${ }^{8}$ Langa, Dicţionar teologic creştin din perspectiva ecumenismului catolic, 241.

${ }^{9}$ Ioan Mircea, Dicţionar al Noului Testament [Dictionary of the New Testament] (Bucharest: Publishing House of the Mission and Bible Institute of the Romanian Orthodox Church, 1995), 473.

${ }^{10}$ Boris Bobrinskoy, Taina Bisericii - Le Mystère de l'Église, cours de théologie dogmatique (Alba-Iulia: Reîntregirea Publishing, 2004), 75.

${ }^{11}$ Stăniloae, Trăirea lui Dumnezeu în ortodoxie, 168.
} 
lives of saints are the records of love. Love is, after all, the only reality with a social and religious formative impact in the life of the faithful.

\section{The Memory of Saints}

When we talk about saints' memory, we talk about God's memory, about what God has preserved with the value of eternity and not with nostalgia. It is a legacy that God has in and with those who have chosen to be pleasing to Him. This reality is clearly expressed by St. Paul, in the following words: "That the God of our Lord Jesus Christ, the Father of glory, may give unto you the spirit of wisdom and revelation in the knowledge of him: the eyes of your understanding being enlightened; that you may know what is the hope of his calling, and what the riches of the glory of his inheritance in the saints, and what is the exceeding greatness of his power to us-ward who believe, according to the working of his mighty power, which he wrought in Christ, when he raised him from the dead, and set him at his own right hand in the heavenly places..." (Ephesians 1:17-20) The riches of the glory of God and of His inheritance is in the saints. Believers cannot be saints without being part of the wealth of God's glory. There is no private holiness, holiness is always communautaire - it is relational. For this reason, to be a saint necessarily entails being in the richness of God's saints, to be God's heritage, to be His memory, to be assimilated in His existence. "Christians are saints not only by simply choosing by the virtue of the covenant, but by the fact that they are introduced into the community of God through Jesus Christ." ${ }^{12}$ This is the way by which the memory of the saints appears. The man who is holy is crossed by the presence of God in a way similar to how Jesus Christ was crossed by heavenly glory on the Mount of Transfiguration. In these circumstances the memory of the saints from the perspective of God is a kind of overlapping of the divine glory with the glory which every believer can attain through grace. We can talk about the encounter within Himself, at the level of the divine glory, carried on by God and in which we are included.

When we talk about the memory of the saints we consider a three-dimensional value of the holiness and of the holy, as well as an affiliation of the holiness and of the holy. In other words, we talk about a divine value, a religious value and a human communautaire value. Every saint belongs to God, belongs to the Church and belongs to a community of believers. This three-dimensionality of affiliation escapes the power and intent of humanity and it must belong to the power and work of the Holy Spirit. The memory of the saints as an inheritance of God belongs to the infinite work, but completed in believers by the Holy Spirit. "It is true that salvation and sanctification of men is a joint work of the three Persons of the Holy Trinity, but it takes place through the participation of the divine life communicated by the Holy Spirit." ${ }^{13}$ We note that the Holy Spirit does not communicate a form of life at the level of information, but the form of life which He communicates is at the level of existence. Holy Spirit does not speak about saints, but the Holy Spirit represents Himself in the life of the saints, in their plenar existence. In other words, God expects holiness from all the faithful. "Such experience is expected from everyone, because the Holy Spirit Who, in the Old Testament was given only to a limited number of persons, now, through the sacrifice of Jesus Christ, became the possession of all." ${ }^{14}$ The expression of Jesus Christ "Receive the Holy Ghost!" from John 20:21-23 ("Then said Jesus to them again, Peace be unto you: as my Father hath sent me, even so send I you. And when he had said this, he breathed on them, and saith unto them, Receive you the Holy Ghost: Whose soever sins you remit, they are remitted unto them; and whose soever sins you retain, they are retained." (John 20:22)) is surrounded by some severe specifications. You are sent by Me as I am sent by the Father and you will keep sins and you will forgive sins as I keep and as I forgive. This is not an administrative authority, but it is a transcendent spiritual one. It claims a prestigiously Christic spiritual attitude. Keeping and forgiving sins does not require administration, but involves spirituality, holiness, and spiritual fullness. We are dealing with a continuous presence in the present tense of the expression from the prayer Our Father: "... Thy will be done in earth, as it is in heaven." (Matthew 6:10)

In conclusion, when we talk about the memory of the saints, we talk about a divine presence of the Holy Spirit in some of His chosen ones. The Christological accent, in this case, is exactly the Holy Spirit. From the Father through Christ in the Holy Spirit the heavenly holiness has an impact which derives from God in

\footnotetext{
${ }^{12}$ Ion Bria, Dicţionar de teologie ortodoxă [Dictionary of Orthodox Theology] (Bucharest: Publishing House of the Mission and Bible Institute of the Romanian Orthodox Church, 1994), 344.

${ }^{13}$ Eduard Ferenţ, Pneumatologia [Pneumatology] (Bucharest: Publishing House of the Roman-Catholic Archdiocese, 1999), 341.

${ }^{14}$ John N. Oswalt, Chemaţi să fie sfinţi [May They Be Called Saints!] (Oradea: Cartea Creştină Publishing, 2008), 150.
} 
the social and religious formation of the faithful, in general, and of the saints, in particular. This memory captures not only the remembrance but also captures the divine inheritance in the saints, a legacy that includes God's love, Jesus Christ as Easter sacrificed in the communion of those taking part to the divine life and the Holy Spirit as the One Who locks into the eternal time the way of being of saints.

\section{The Image of Saints in St. Gerard of Cenad}

The name saint given to Gerard of Cenad should be stressed not only because of the canonization offered by the Church, but also from the springs of his complex existence, at the human level and faithful bishop. Maria Micle notes the following: "...involved in the evangelization of Central Europe, he notes in his writings observations, religious and political attitudes..."15 This few-worded record shows us Gerard of Cenad as a European, as an observer of the European society and as one who has both religious and political attitudes. $\mathrm{He}$ must be regarded as a man of the people, but at the same time as a believer of the believers. Referring to his spiritual dimension, Martin Roos notes the following: "Gerard's spiritual image is also dominant, which on the political and ecclesiastical realm lies before us, in the light of history, clearer and brighter than any other figure of the Early Catholic Church in Hungary." ${ }^{16}$ Under these circumstances we do not only talk about St. Gerard of Cenad, but we talk about an amount of historical images of saints and people found within him, which he re-offers to us. The evocation of Gerard of Cenad's personality should be of third millennium value. The contemporary society is becoming more contemporary with the existence of every saint believer. "The third Millennium - notes Nicolae Corneanu - transforms Fathers' thought and spirituality into a safe base for getting closer and, finally, the reunification of Churches. ${ }^{17}$ In other words, St. Gerard of Cenad should have a role in the present and the future. We have to retrieve and expose his thinking so as, through his personality, to influence the religious value of the contemporary Christianity and to determine it positively.

The saintly image in St. Gerard of Cenad should be seen through the idea of their birth and his birth. The schismatic Christian era, an age which asks for his birth, significantly emphasizes the importance of his birth to become saint. Moreover, he pays his debts in the most honourable way possible to the expectations of the centuries in which he lives. "His position within the episcopate from Hungary, especially in the era of the tumultuous struggles for the throne carried around King Samuel Aba, constitutes a dominant attitude, of leadership, but at the same time it is exposed and dangerous. His violent death was nothing but the result of this courageous involvement and it is considered the first Christian martyrdom on the Hungarian Pannonian territory." ${ }^{18}$ This way, the birth of saints, as divine providence, as well as the memory of the saints, as divine inheritance, find their meaning and statement in what was Gerard of Cenad through his faith, for which he would pay the ultimate and holy price. The expressions birth and memory in the context of our research have the purpose of marking the particularity of the exceptional life of Gerard of Cenad to universalise the important impact of this life. This universality is not only an evocative one, but also one through which we present in a contemporary light the image of the believers until him for the illumination of those following him.

Within the idea of God's saints, Gerard of Cenad earns his primacy and place through birth, education, and ministry. He was born in the late tenth century, in the middle of one of the greatest crises of Christianity. Due to an illness, "...his parents were concerned and made a covenant that if he recovered his health, they would offer him to God and thus at only five years of age, he was sent to the Benedictine Monastery of San Giorgio..." ${ }^{19}$ This birth and childhood aligns with the history which claimed his existence. We speak about

\footnotetext{
${ }^{15}$ Maria Micle, "Re-lectură a scrierii lui Gerard de Cenad din perspectivainterferenţelor culturale" [Re-reading Gerard of Cenad's Writings from the Perspective of Cultural Interference], in Filosofia Sfântului Gerard de Cenad in context cultural și biografic [ The Philosophy of St. Gerard of Cenad in Cultural and Biographical Context], ed. Claudiu Mesaroş (Szeged: JATE Press, 2013), 190.

${ }^{16}$ Martin Roos, "Izvoare istorice cu privire la Vita Gerardi" [Historical sources on Vita Gerardi] in Filosofia Sfântului Gerard de Cenad in context cultural și biografic [The Philosophy of St. Gerard of Cenad in Cultural and Biographical Context], ed. Claudiu Mesaroş (Szeged: JATE Press, 2013), 28.

${ }^{17}$ Nicolae Corneanu, Miscellanea Patristica (Timişoara: Amacord Publishing, 2001), 12.

${ }^{18}$ Martin Roos, "Izvoare istorice cu privire la Vita Gerardi," 28.

${ }^{19}$ Ştefan Grosu, "Viața Sfântului Gerard, de la legendă la adevăr" [Life of St. Gerard, from Legend to Reality] in Filosofia Sfântului Gerard de Cenad in context cultural și biografic [The Philosophy of St. Gerard of Cenad in Cultural and Biographical Context], ed. Claudiu Mesaroş (Szeged: JATE Press, 2013), 61.
} 
his education, about a passion for the existence of God and the universality of knowledge. "Saint Gerard of Cenad <turns out to be an encyclopaedic spirit, and his writings are provided with reflections and quotes... from the immense ancient, biblical, and patristic dowry>, but also reflect his own, rather bold, thinking." ${ }^{20}$ This reality was suggested by the Prophet Daniel when he spoke of the wise: "And they that be wise shall shine as the brightness of the firmament; and they that turn many to righteousness as the stars forever and ever" (Daniel 12:3). Finally, his ministry is nothing less. The way Gerard of Cenad knows how to believe, to write, and to live is successful and unique. "As Protomartyr of Pannonia, Gerard becomes the true image of the Christian ideal since the beginning, who knows how to blend, in an extremely tight manner, in only one being, faith and life." ${ }^{21}$ He takes the image of the Holy Martyrs, customizes it in himself, becoming saint and martyr, but at the same time, offers to future generations this image, at the level of meditation and of practical life of faith.

In conclusion, the evidence of his life highlights the nuances of Christ's existence. This highlighting remains to us through his writings and life as an impact in the social formation of later generations, but also as a religious impact for the formation of the life of faith of Christians.

\section{References}

Anania Valeriu, Bartolomeu. Cartea profetului Isaia [The Book of Prophet Isaiah]. Bucharest: Anastasia Publishing, 1999.

Bobrinskoy, Boris. Taina Bisericii - Le Mystère de l'Église, cours de théologie dogmatique. Alba-Iulia: Reîntregirea Publishing, 2004.

Bria, Ion. Dicţionar de teologie ortodoxă [Dictionary of Orthodox Theology]. Bucharest: Publishing House of the Mission and Bible Institute of the Romanian Orthodox Church, 1994.

Corneanu, Nicolae. Miscellanea Patristica. Timişoara: Amacord Publishing, 2001.

Crainic, Nichifor. Sfinţenia, împlinirea umanului [Holiness, Human Fulfillment]. Iaşi: Publishing House of the Metropolitan of Moldavia and Bukovina, 1993.

Ferenţ, Eduard. Pneumatologia [Pneumatology]. Bucharest: Publishing House of the Roman-Catholic Archdiocese, 1999.

Grosu, Ştefan. "Viața Sfântului Gerard, de la legendă la adevăr" [Life of St. Gerard, from Legend to Reality]. In Filosofia Sfântului Gerard de Cenad în context cultural și biografic [The Philosophy of St. Gerard of Cenad in Cultural and Biographical Context], ed. Claudiu Mesaroş. Szeged: JATE Press, 2013.

Langa, Tertulian. Dicţionar teologic creştin din perspectiva ecumenismului catolic [Christian Theological Dictionary from the Perspective of Catholic Ecumenism] Cluj-Napoca: Dacia Publishing, 1997.

Laporte, Jian. Părinţii greci ai Bisericii [Greek Fathers of the Church]. Târgu Lăpuş: Galaxia Gutenberg Publishing, 2009.

Micle, Maria. "Re-lectură a scrierii lui Gerard de Cenad din perspectiva interferenţelor cultural" [Re-reading Gerard of Cenad's Writings from the Perspective of Cultural Interference]. In Filosofia Sfântului Gerard de Cenad in context cultural și biografic [The Philosophy of St. Gerard of Cenad in Cultural and Biographical Context], ed. Claudiu Mesaroş. Szeged: JATE Press, 2013.

Mircea, Ioan. Dicţionar al Noului Testament [Dictionary of the New Testament]. Bucharest: Publishing House of the Mission and Bible Institute of the Romanian Orthodox Church, 1995.

Oswalt, N. John. Chemaţi să fie sfinţi [May They Be Called Saints!]. Oradea: Cartea Creştină Publishing, 2008.

Roos, Martin, "Izvoare istorice cu privire la Vita Gerardi" [Historical sources on Vita Gerardi]. In Filosofia Sfântului Gerard de Cenad în context cultural și biografic [The Philosophy of St. Gerard of Cenad in Cultural and Biographical Context], ed. Claudiu Mesaroş. Szeged: JATE Press, 2013.

Stăniloae, Dumitru. Trăirea lui Dumnezeu în Ortodoxie [Experiencing God in Orthodoxy]. Cluj-Napoca Dacia Publishing, 1993.

\footnotetext{
${ }^{20}$ Ştefan Grosu, "Viața Sfântului Gerard, de la legendă la adevăr" [Life of St. Gerard, from Legend to Reality], in Filosofia Sfântului Gerard de Cenad in context cultural și biografic (The Philosophy of St. Gerard of Cenad in Cultural and Biographical Context), ed. Claudiu Mesaroş (Szeged: JATE Press, 2013), 59.

${ }^{21}$ Martin Roos, "Izvoare istorice cu privire la Vita Gerardi" [Historical sources on Vita Gerardi], in Filosofia Sfântului Gerard de Cenad in context cultural și biografic (The Philosophy of St. Gerard of Cenad in Cultural and Biographical Context), ed. Claudiu Mesaroş (Szeged: JATE Press, 2013), 28.
} 
William, Macdonald. Comentariu la Noul Testament (Original title: Comentario biblico). Bielefeld: CLV Christliche Literatur-Verbreitunge.V., 1998. 